\title{
Sejl i jorden
}

\section{Om træer og andre svært beskrivelige ting i palæstinensisk digtning}

Ah, what an age it is

When to speak of trees is almost a crime

For it is a kind of silence about injustice. ${ }^{\mathrm{I}}$

Litteraturhistorien handler ikke blot om historie eller blot om litteratur. ${ }^{2}$ Den handler altid om begges brug og funktion. I en palæstinensisk kontekst er digterens funktion overvejende blevet defineret inden for modstandsdigtningens paradigme: den revolutionære digter, den engagerede digter, digteren som kæmper osv. Selvom disse digterfunktioner har domineret kulturelt, er de dog også ofte blevet udfordret. Den overordnede friktion i intranationale debatter om palæstinensisk kulturproduktion siden 1960'erne har været mellem de politiske og kollektive konfigurationer af den poetiske tekst på den ene side og dens mere personlige og subjektive udtryk på den anden. Blandt de mange digtere, som har søgt at modstå sig den politiske digtnings spændetrøje, har ingen som Mahmoud Darwish (1942-2008) - ofte kaldet Palæstinas stemme og en af den arabiske verdens mest berømte digtere - så længe og så vedholdende talt for fuld poetisk autonomi fra det politiske og politiserede udtryk. Efter mere end et kvart århundredes insisteren på digtets æstetiske mangfoldighed, følte han sig dog stadig i 2005 nødsaget til at retfærdiggøre indholdet af sin seneste samling Ka-zahr al-lawz aw ab 'ad [Som mandelblomster eller fjernere]:

$6 \mathrm{I}$ will confess to all the scowling judges that I have given up writing direct political poetry with limited connotations, without giving up the concept of aesthetic resistance in the broad sense of the word... not because circumstances have changed, and we have moved from resistance to the negotiation table...but because poetic language must always be in a state of flux...It is not right that a Palestinian poet should not be allowed to sit on a hill and gaze at the sunset, or listen to the call of the body or the distant flute... ${ }^{3}$ 
Hvorvidt en palæstinensisk digter eller kunstner kan tillade sig at beskrive en solnedgang, er en koncis formulering af en af de mest basale problemstillinger i palæstinensisk kulturproduktion. Spørgsmålet om tilladelse dukker op igen og igen i den interne kulturdebat. Hvem skal bestemme, hvad der er poetisk eller tilstrækkeligt poetisk? Hvem skal afgrænse poesiens primære funktion? Og hvor skal palæstinensisk identitet spores? I teksten eller uden for den; hos digteren eller hos læseren? For palæstinensiske kunstnere har retten til at beskrive kroppen eller en solnedgang været og er i en vis udstrækning fortsat begrænset af de mere presserende krav, der uvægerligt følger med en truet og ustabil social virkelighed. Om end hans løbebane og popularitet må siges at være exceptionel, udgør Darwishs samlede værker og deres reception et af de mest indsigtsgivende sites for en vedvarende forhandling mellem en national og ikkenational kulturæstetik. Darwish er selvfølgelig ikke alene. Murid Barghuthi, Walid Khazindar, Ghassan Zaqtan og Zakaria Muhammed fra 1970'er- og 1980'er-generationerne har alle deltaget i samme projekt. Fra slutningen af 1990'erne er en ny gruppe yngre digtere såsom Anas alAili, Tariq al-Karmi og Kifah Fanni begyndt at eksperimentere med digtets rammer, og hvad det kan rumme. Atanaffas al-ufuq al-mushmis indrømmer eller besværger al-Aili i første-person i sit Plante-digt, som jeg nærlæser nedenfor. "Jeg indånder den solmættede horisont.” Det samme gør andre nye navne, f.eks. Walid al-Shaykh, Ghada al-Shafi i, Murad al-Sudani, Mahmoud Abu Hashhash og Raja Ghanim. ${ }^{4}$

I denne artikel søger jeg at problematisere de kategorier, kritikere normalt benytter til at beskrive palæstinensisk litteratur. I forlængelse heraf præsenteres endvidere et udvalg af digte skrevet af de såkaldte nye palæstinensiske digtere. Disse tekster benytter sig alle af agrariske troper som træet, jorden, landet - troper med traditionelt klare, entydige nationalistiske ladninger - og tilfører dem et kompliceret og, til tider, kontroversielt indhold. Læsninger af disse digte giver ikke blot indblik i nogle af de retninger, som samtidig palæstinensisk digtning bevæger sig i. De hjælper os også til bedre at forstå, hvad der i en palæstinensisk sammenhæng forbliver en vedvarende spænding mellem digtets subjektiv-æstetiske og politiske potentialer.

$$
* * *
$$

Standardudlægningen af udviklingen af palæstinensisk litteratur kan nemt læses som en forenklet oversigt over nationalpolitiske kernebegivenheder. Salma Khadra Jayyusis periodebaserede oversigt i Anthology of Modern Palestinian Literature er prototypisk. ${ }^{5}$ Den skelner mellem før-1948, 1948-1967 og post-1967 litterære produktioner. Den fremhæver ikke den litterære begivenhed, såsom f.eks. udgivelsen af Murid Barghuthis samling Qașā’id al-raṣiff [Fortovsdigte] i 1980, som indeholdt usædvanligt lavmælte digte for sin tid, eller lydoptagelsen i 1983 af Darwishs digt "Madīh al-ẓill al- 'âlī" [Lovprisning af den stigende skygge], der øjeblikkeligt opnåede ikonisk status. Det er ikke digtet, novellen eller selve værket, der står i centrum. Ej heller forfatterne. 


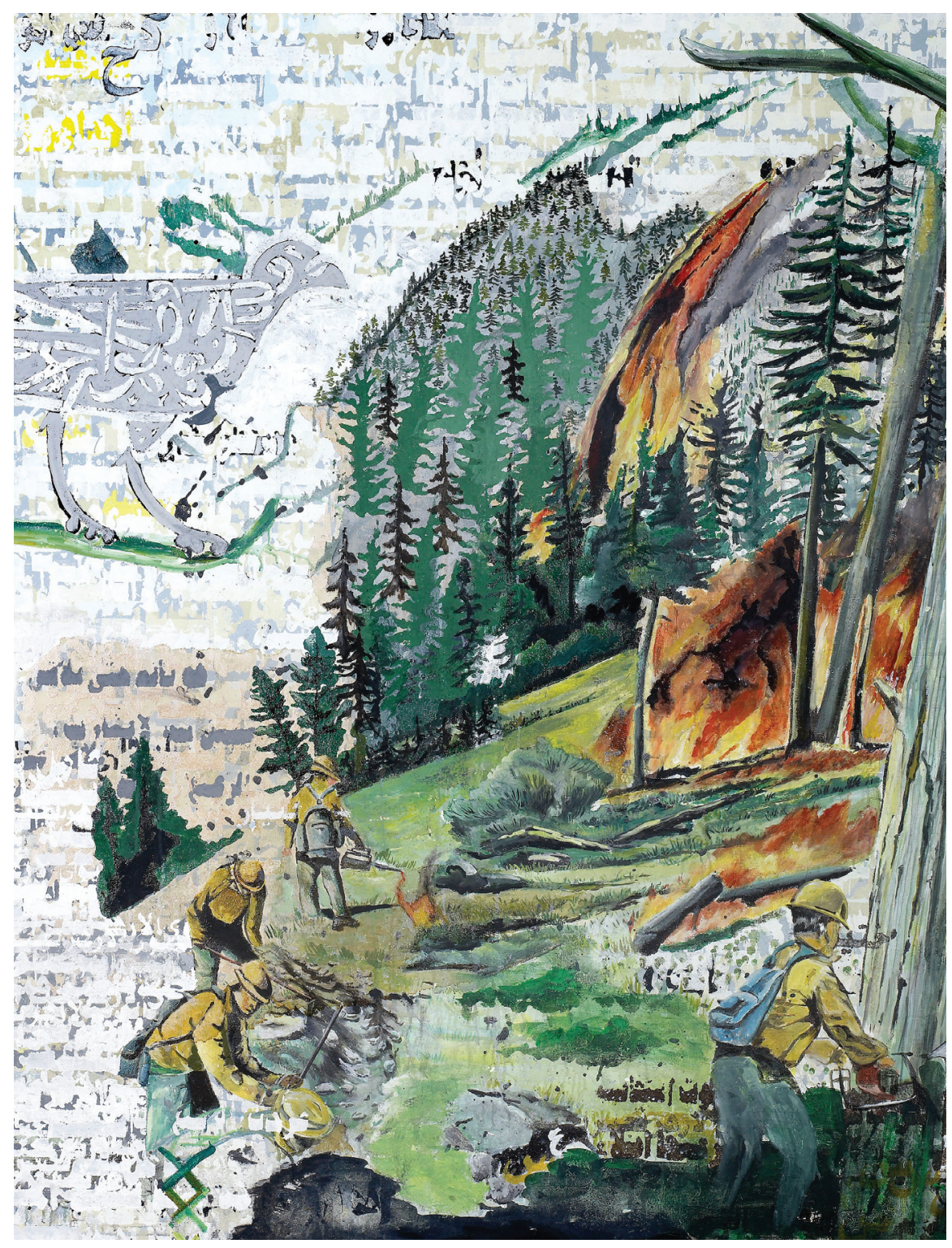

Jeffar Khaldi: Writer. Olie på lærred, 190 x 150 cm, 2008. (C) Jeffar Khaldi. Courtesy of B21 Gallery. 
Et sådant fokus på ekstralitterære, nationale nøgleepoker i fremstillingen af litterære strømninger og bevægelser er selvfølgelig ikke udelukkende et palæstinensisk fænomen. Periodemodellen er et ganske almindeligt og ofte benyttet strukturelt princip i litterære kanonprojekter og særligt i den udgave, der baserer sig på temporale -ismer (neoklassicisme, romanticisme, modernisme osv.). ${ }^{6}$

I en palæstinensisk kontekst er den dominerende anvendelse af historisk kronologi og konstruktionen af litterære generationer inden for periodemodellen uløseligt knyttet til store, traumatiske begivenheder forbundet med kamp og tab, der fortsætter ind i nutiden. Således taler man vanligvis i grove træk om digtere og forfattere som tilhørende enten nakba-generationen (den oprindelige katastrofe i 1948); naksa-generationen (1967-krigsgenerationen); eller Intifadagenerationen (1987-93). Som forfatter kan man naturligvis godt falde uden for disse kategorier og f.eks. tilhøre en præ- eller post-nakba-generation eller mere end én generation på samme tid, men det rykker ikke væsentligt ved den overordnede skematik. Indtrykket forbliver, at en given generations produktion er skabt af og skal læses i lyset af et særligt voldsomt historisk øjeblik. En sådan måde at læse poesi på fastholder, at digtet altid er født af en krise, og at det nødvendigvis må være en respons på krise:

64 Modern Palestinian experience is harsh, unrelenting, and all-penetrating...There is no escape. For the writer to contemplate an orientation completely divorced from political life is to belie reality, to deny experience; for to engross oneself for too long in "normal" everyday experiences is to betray one's own life and one's own people. This means that Palestinian writers have little scope for indulging in escapism; they are compromised by the events of contemporary history even before they are born. The luxury of choosing one's past, of selecting memories, of re-arranging relations that transcend events and external circumstances, is not theirs; they have become permanent exiles, the prototype of the strangers of all times, struggling against obstacles of every kind and magnitude. ${ }^{7}$

Standardudlægninger som Jayyusis viser tydeligt, i hvor høj grad kunstnerens og kunstens rolle i palæstinensisk kultur er funktionelt defineret og kollektivt determineret. Intet andet sted er dette tydeligere end i poesien, som fortsat er den mest populære og værdsatte udtryksform overhovedet både i det palæstinensiske og bredere arabiske samfund. ${ }^{8}$ Ifølge en lang og stolt mundtlig tradition er en digter en synlig, hørbar og offentlig person, der beskæftiger sig med fællesskabets problemer, specielt i svære tider. Dette har været den palæstinensiske digters konventionelle rolle siden begyndelsen af det 20. århundrede og i særlig utvetydig grad siden forfatter, journalist og aktivist Ghassan Kanafani (1936-1972) dannede shi' $r$ al-muqāwama [modstandsdigtning] i 1966 som betegnelse for tekster skrevet af digtere i det besatte Palæstina. ${ }^{9}$

Jayyusis beskrivelse er ikke kun prototypisk, men også en af de mest autoritative skildringer af udviklingen i palæstinensisk litteratur i det 20. århundrede. Hendes fremstilling er et godt eksempel på den kulturelle situation, som Fredric Jameson kortlagde i sit berømte (eller notoriske) 1986-essay “Third-World Litera- 
ture in the Age of Multinational Capitalism."' Io I modsætning til kulturproduktionen i den postmodernistiske "første verden" [first world], siger Jameson, så frembringer tekster fra den tredje verden altid prima facie politiske læsninger, der både er skrevet og skal forstås som nationale allegorier: “... the telling of the individual story and the individual experience cannot but ultimately involve the whole laborious telling of the experience of the collectivity itself." "II

Jayyusi, og med hende mange andre kritikere, sammensmelter uden forbehold den palæstinensiske litterære tekst og socio-politiske kontekst. Mens nyere palæstinensisk litteraturhistorie kommer til at fremstå som homogen og syntetiseret, sker der samtidig en marginalisering af de stemmer og grupperinger, der ikke passer ind i en sådant dominerende fortælling. Jayyusis historicistiske rammefortælling med $1948 \mathrm{i}$ centrum er i denne forstand lige så reduktiv som Jamesons tre-verdenermodel. Salah D. Hassan kondenserer rammende både de politiske og litterære implikationer af at anskue 1948 som et uafvendeligt, alt-definerende øjeblik:

Uf The problem with this approach to defining the specificity of Palestinian culture is the implication that the Palestinian nation comes into existence as a consequence of Zionist oppression... This line of argument fails to establish convincingly the particularity of Palestinian literature, but more importantly it reduces the significance of Palestinian artistic expression to a second-order phenomenon that, like the Palestinian nation, is an effect of conditions created in large part by "the Zionist movement." ${ }^{2}$

Indrulleringen af staten Israels etablering som fundamental for palæstinensisk kultur betyder ikke blot, at palæstinensisk litteratur kommer til at fremstå som reaktionær i allerbogstaveligste forstand (dvs. som et "second-order phenomenon"); det betyder også, at en særlig type skrivning privilegeres, nemlig den der taler til og nemt kan kædes sammen med de barske oplevelser ("harsh, unrelenting and allpenetrating”), som er uløseligt forbundne med 1948. En palæstinensisk litteraturkritik, som har den historiske katastrofe som udgangspunkt, fokuserer overvejende på det tematiske og fastfryser dermed det kunstneriske udtryk. En sådan kritik må nødvendigvis afstumpe eller afgrænse den pågældende litterære tradition. I studier af palæstinensisk litteratur er det da også tydeligt, at det korpus, som er skrevet før 1948, ikke bliver til meget andet end en parentisk bemærkning. I den anden ende opstår et ikke mindre problematisk spørgsmål. Hvad sker der, når et dominerende tema pludselig bliver "forældet"? Hvad sker der, når det ikke længere har resonans hos digtere og læsere? Vil den pågældende "gamle" digtning så også blive irrelevant og anset som upoetisk?

I 1999 udgav Bayt al-shi`r [House of Poetry] i Ramallah på Vestbredden en antologi

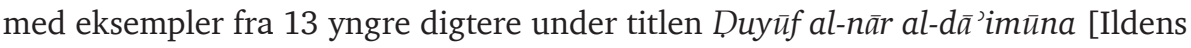
evige gæster]. ${ }^{\mathrm{I3}}$ Antologien vakte umiddelbar debat blandt kommentatorer, som kaldte den et længe ventet paradigmeskift - et rigtigt brud med en tradition domineret af værker med politiske og nationalistiske budskaber. Ifølge kritikerne repræ- 
senterer disse yngre digtere - med reference til den politiske udvikling i 1990'erne og en alt for hurtig og velkendt sammensmeltning af tekst og kontekst - en afpolitiseret, post-Oslo poetik. ${ }^{14}$ Anas al-Aili er et godt eksempel.

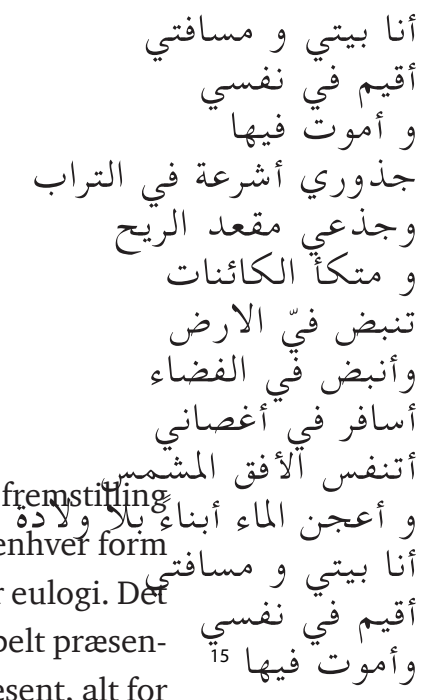

6 Jeg er mit hjem og min afstand

Jeg bor i mig selv

og dør der

Mine rødder er sejl i jorden

min stamme et sæde for vinden

som andre kan læne sig op ad

Landet pulserer i mig

Jeg pulserer i det åbne rum

og rejser rundt i mine grene

indånder den solmættede horisont

og ælter vand til børn født uden veer

Jeg er mit hjem og min afstand

Jeg bor i mig selv

og dør der. ${ }^{16}$

Anas al-Aili's digt "Plante" indbyder til mindst to læsninger. Den første er en realistisk repræsentation af et træ, som taler helt naturligt fra sit fikserede udgangspunkt - jeg er et træ i jorden; dette er mit liv. Den anden består af en rejse og migrationssymbolik, som er kendetegnet ved en mere drømmende, fantastisk tekstur. Judhūrī ashri 'atun fì al-turāb [mine rødder er sejl i jorden]: det jordbundne og det maritime smelter sammen. Wa- 'a 'janu al-mā' abnā'an bi-lā wilāda [og (jeg) ælter vand til børn født uden veer]: det botaniske flyder ind i det anatomiske. Grænsen mellem stasis og dynamis opløses hele tiden.

En bogstavelig fortolkning af "Plante" som (ganske simpelt) en monolog fremført af et træ bliver både beriget og kompliceret af den meget stærke tekstuelle frem- 
hævelse af et lyrisk jeg. Hvert eneste vers er holdt i første person ental og indkorporerer ofte mere end én eksplicit første-persons markør, for eksempel anā baytī wa-masāfatī [jeg er mit hjem og min afstand]. Man hører ikke blot et træ tale, men også det lyriske jegs stemme. På samme måde som der på det metaforiske plan forekommer en spænding mellem det realistiske og det fantastiske, finder en duel sted her mellem stemmer, der konkurrerer om tekstuel autoritet. Disse "dueller" bliver selv til subtile undertekster i digtet. Hvis vi læser bag om realismen, opdager vi nemlig et digt - en anti-sonet - hvor den poetiske stemmes enhed er blevet polyfonisk. I endnu en dobbelt forstand finder vi endvidere, at digtets jeg residerer ikke kun i selvet eller sjælen [al-nafs $>$ nafsī], men også i åndedrættet, hvor det artikulerer sig via indånding og udånding [alnafas $>$ atanaffas.$^{\mathrm{r}}{ }^{7}$

Al-Ailis jordlige, grønne og ekspressionistiske digt skal forstås inden for en kulturel tradition, hvor træer - i særdeleshed oliventræer - fungerer som almindelige troper for rodfasthed. I Carol Bardensteins komparative studie af israelske og palæstinensiske diskurser om indfødthed optræder træer, appelsiner og kaktusser som nogle af de mest emblematiske "hypersaturated and contested symbols" overhovedet. ${ }^{18}$ I modsætning til træerne i de palæstinensiske tekster, som Bardenstein undersøger, gør al-Ailis talende træ dog ikke sin sædvanlige poetiske pligt. Ulig vanlige repræsentationer af oliventræet nægter al-Ailis træ for eksempel at bære på én speciel og begrænset symbolsk mening eller at fungere som et "repository for Palestinian memory." Hans træ bærer ikke vidne om de overgreb, som finder sted mod en befolkning, der bliver rykket op med rode. Det modsætter sig heller ikke sin egen oprykning. I stedet udvikler al-Aili en metaforik af migration og bevægelse på tværs af rum som udtryk for en måde, hvorpå man kan være i verden. Man er måske aldrig helt hjemme, på sin plads, men man kan godt være selvopretholdende alligevel. Ved at transcendere "mine rødder" og "mit selv" som fikserede, urokkelige steder, mediterer digtet over - og ser ud til at acceptere - et hjemligt rum, som er ustabilt og i stadig bevægelse.

Al-Aili er ikke den eneste blandt nyere palæstinensiske digtere, der overvejer stedets og selvets ustabile natur. Få beskriver dem dog i så organiske, nærmest harmoniske termer. Tariq al-Karmi vender hjem til sit "vindens hus," men hører tydeligvis ikke til der og kan slet ikke finde nogen form for ro der, selv ikke i søvnen. Hans poetiske jeg er tynget af sted i allerbogstaveligste forstand. Dette sted er ikke mindre end bi lā $d \bar{\imath} .$. [mit h j e m l a n d]:

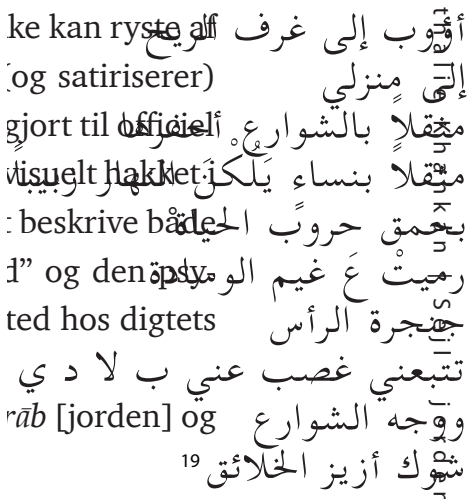


6f Jeg vender tilbage til vindens værelser

mit hjem

tynget af gaderne som jeg udmejsler

tynget af kvinderne der tygger på dagen som var det en rosin

af livets latterlige kampe

Jeg lader hovedet dumpe

ned i pudeskyer

forfulgt mod min vilje af mit h j e m l a n d

ansigter fra gaderne

torne fra skabningernes summen

Inden for et palæstinensisk nationalt og nationalistisk leksikon er denne fremstilling af bi lā dī særlig slående, fordi den så eftertrykkeligt er blevet tømt for enhver form for positiv konnotation. Her er hjemland ikke genstand for nostalgi eller eulogi. Det er ikke et smukt paradisisk sted i fortid eller fremtid. Det er ganske simpelt præsenteret som her og nu tidsmæssigt og, i en anden forstand, som alt for præsent, alt for meget til stede. Bi lā dī bliver dog ikke blot afvist som en byrde her. Hos al-Karmi forvandles det til en reel forfølger - til noget eller nogen som man ikke kan ryste af sig eller komme af med. Den typografiske fremstilling efterligner (og satiriserer) "Bilādī," teksten og melodien som det Palæstinensiske Selvstyre har gjort til officiel nationalsang i 1996. På samme tid er mit hjemland også emfatisk og visuelt hakket $\mathrm{i}$ småbidder som bi la $\bar{d} \bar{\imath}$ - en særdeles velanrettet måde for digteren at beskrive både den faktiske fysiske fragmentering af Palæstina som "mit hjemland" og den psykologiske fragmentering af tilhørsfølelsen til Palæstina, der finder sted hos digtets talende jeg.

Som al-Karmi taler Kifah Fanni også om fremmedgørelse fra al-turāb [jorden] og al-arḍ [landet]:

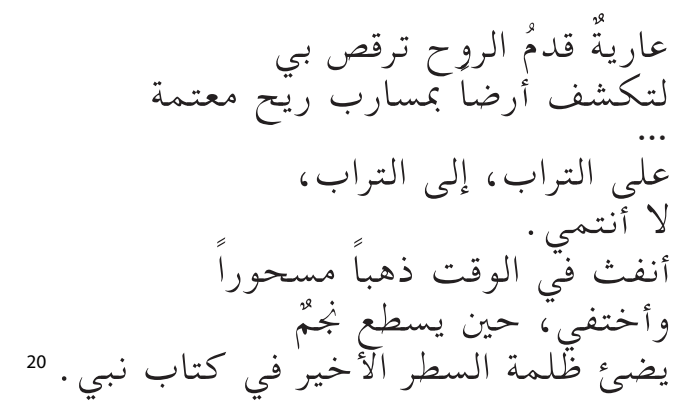


6f Nøgen er åndens fod som danser i mig

for at åbenbare et land (fyldt) med en mørk vinds veje

På jorden, til jorden

hører jeg ikke (til)

Jeg udånder fortryllet guld ind i tiden

og vil forsvinde når en skinnende stjerne

oplyser mørket i det sidste vers i profetens bog.

Al-bilād, al-wațan [hjemland, nation] og deres kognater deltager i et af de mest ladede semantiske felter i det palæstinensiske poetiske register. En national historie, som siden begyndelsen af det 20 . århundrede har handlet om Palæstinas reduktion, erosion og ekspropriation som land, har naturligvis efterladt sit spor i litterære repræsentationer. Allermest tydeligt er "land" og "jord" blevet tømt for deres konnotationer til landbrug, natur og miljø til fordel for rene nationalistiske indkodninger. Åbningssekvensen til Ghassan Kanafanis berømte 1962 kortroman Mænd i solen (da 1975) er et paradigmatisk eksempel på en sådan indkodning, der vanligvis fremkalder en høj grad af tab, længsel og savn:

16 Abu Qais hvilede sit bryst på den fugtige jord [al-turāb al-nadiyy], og jorden [al-arḍ] begyndte at banke under ham med trætte hjerteslag, som rystede gennem sandkornene og brød igennem hans krops celler. Hver gang han lagde sig med sit bryst mod jorden [alard] fornemmede han den banken, som om jordens hjerte [al-ard] havde banet sin vanskelige vej mod lyset fra de dybeste lag af helvede... lige siden den første gang han havde lagt sig der... Hver gang indåndede han jordens duft [rā'ihat al-ard]. Som han lå på den forestillede han sig, at han duftede til sin kones hår, når hun lige var kommet ud fra et koldt bad. Nøjagtig den samme duft, duften af en kvinde efter et koldt bad, hvis fugtige hår dækkede hans ansigt. Den samme banken, som ganske forsigtigt at holde en lille fugl i dine hænder. ${ }^{21}$

I et forsøg på at kompensere for det faktiske tab af og fysiske forbindelse med hjemlandet, har palæstinensiske forfattere og digtere ofte forsøgt ikke blot at beskrive det, som de husker det, men også at bygge nye, alternative hjemlande i deres værker, i selve teksten. Fremstillinger som f.eks. Kanafanis udgør den kanoniske kontekst, inden for hvilken al-Karmis og Fannis tekster kan læses som unormale. Fremmedgørelse og afvisning er relativt sjældne poetiske reaktioner på et land, der hele tiden skrumper ind og ganske langsomt forsvinder. Det samme kan siges om træ-digte, hvor en højkonventionel symbolik nu pludselig nedbrydes, og hvor det ikke længere er muligt entydigt at afkode symbolets (dvs. træets) signal.

Det bliver hurtigt tydeligt under læsningen af Walid al-Shaykhs "Haithu lā shajar" [Hvor der ingen træer er], at digtet ikke har den ekspansion eller bevægelse, som kan spores i al-Aili's "Plante."22 Dets tone er nøgtern men også insisterende med sine gentagelser: 


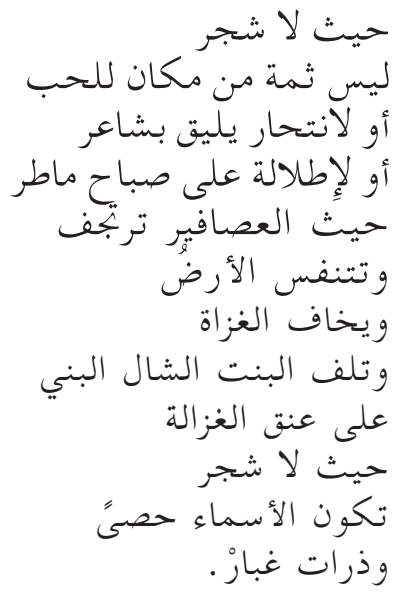

64 Hvor der ingen træer er, er der ikke rum til kærlighed eller til et selvmord som kunne egne sig for en digter eller til et første glimt på en regnfuld morgen hvor fuglene skælver landet trækker vejret angriberne bliver bange og en pige vikler sit brune sjal omkring halsen på en gazelle. Hvor der ingen træer er, er navne blot småsten og partikler af støv.

Al-Shaykhs digt er en minimalistisk visualisering af et sted, som hverken er defineret af navn eller attribut, men derimod af en række dobbelte negativer. Kortfattet men omhyggeligt, indfanger teksten en god bid af alt det, som ikke kan være der, hvor der ingen træer er. Det er et ugeografisk sted. Navne er ikke navne, men sten og støv. Og som læsere sættes vi helt fri til at forestille os, hvor det mon kunne være.

\section{Noter}

I Bertolt Brecht, "To Posterity" [oprind. "An die Nachgeborenen"], i Selected Poems, overs. H. R. Hays (New York: Reynal \& Hitchcock, 1947).

2 Nærværende artikel er baseret på uddrag af Breathing Sun-Drenched Horizons: The Possibility of Poetry in Post-Oslo Palestine, ph.d.-afhandling, University of California, Berkeley, maj 2009.

3 Fra tale afholdt i Khalil Sakakini Cultural Center, Ramallah i anledning af udgivelsen af hans seneste samling. Tale trykt som "Mihnat al-shā'ir" [Digterens profession] i Mahmoud Darwish, Hayrat al- '`'’'id: maqālāt mukhtāra (Beirut: Riad El-Rayyes Books, 2007), 150.

4 Se f.eks. Nuri al-Jarrah, "Shu'arā' min Filasțīn al-jadīda" [Digtere fra et nyt Palæstina], al- 
Shu 'arā’ 6 (1999): 205-220. For en mere udførlig diskussion af tilsynekomsten af og den kritiske diskurs omkring de såkaldte "New Palestinian Poets," se Khankan, 2009.

5 Salma Khadra Jayyusi, red., Anthology of Modern Palestinian Literature (New York: Columbia University Press, 1992); og senere udgivet på arabisk: Mawsū 'āt al-adab al-filasțīnī al-mu 'āșir (Beirut: al-Mu’assasa al- 'arabiyya li al-dirāsāt wa al-nashr, 1997).

6 Genre udgør den anden store tilgang til skematisering af litterær udvikling. Se Chana Kronfelds diskussion af periode og genre som teoretiske modeller og hendes konceptuelle kortlægning af feltet mellem de to, som centrerer litterære bevægelser og trends i et "critical mixed mode." "Theory/History. Between Period and Genre; Or, What to Do with a Literary Trend?" i On the Margins of Modernism: Decentering Literary Dynamics (Berkeley and London: University of California Press, 1996), 37.

7 Jayyusi, 1992, 2-3.

8 Digtets popularitet som udtryksform kan spores til de tidligste eksempler, vi har på præ-islamisk poesi. Som lingvistisk forgænger til Koranen betragtes poesien vanligvis som diwan al- 'arab [arabernes historiske register] og som et vigtigt medium i understregelsen af arabisk identitet og fællesskab. Den arabiske digter beskrives ofte som talsperson for sit samfund, hvis primære rolle er funktionelt betinget, offentlig og social. Poesi rammer i dag fortsat bredt. En digters oplæsning i den arabiske verden kan f.eks. sagtens fylde et fodboldstadium i Damaskus. En digter kan også godt være så populær, at vedkommende modtager en militærbegravelse i Ramallah. Begge eksempler peger på digtets samtidige kollektive relevans.

9 Dvs. før 1967 og som en betegnelse for palæstinensiske forfattere, der arbejdede inden for Israels grænser. Ghassan Kanafani, Adab al-muqūwama fì Filasținn al-muhtalla 1948-1966 [Modstandsdigtning i det besatte Palæstina 1948-1966] (Beirut: Dār al-adab, 1966). Se også Barbara Harlow, Resistance Literature (New York: Methuen, 1987).

Io Fredric Jameson, "Third-World Literature in the Age of Multinational Capitalism," Social Text 15 (1986): 65-88. Lige så berømt er Ahmad Aijazs kritiske respons, "Jameson’s Rhetoric of Otherness and 'National Allegory,"' Social Text 17 (1987): 3-25.

II Eller: "Third-world texts, even those which are seemingly private and invested with a properly libidinal dynamic - necessarily project a political dimension in the form of national allegory..." Jameson, 1986, 85 og 69.

I2 Salah D. Hassan, "Nation Validation: Modern Palestinian Literature and the Politics of Appeasement," Social Text 7521.2 (2003), 18-19. Elmessiri har samme pointe i sin introduktion til A Palestinian Wedding: A Bilingual Anthology of Contemporary Resistance Poetry, overs. A. M. Elmessiri (Washington D. C.: Three Continents Press, 1982).

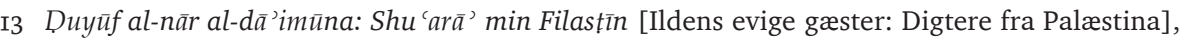
Ghassan Zaqtan, red. (Ramallah: Palestinian House of Poetry, 1999).

I4 Kritikernes "afpolitisering" eller "afpalæstinensering" af 1990'er-generationens tekster er ikke uproblematisk heller. Som hos Jayyusi et al. anvendes Palæstina-spørgsmålet fortsat som centrum og målestok, nu blot med omvendt fortegn. Det er ikke længere Palæstina (som kontinuerlig tragedie og fortløbende traume) og dets eksplicitte tekstuelle tilstedeværelse, som giver mening til digtet. Det er Palæstina-spørgsmålets tydelige fravær i digte som f.eks. al-Ailis "Plante." For en kritik af denne nyskrivning af palæstinensisk poesi, se Abdul Rahim al- Shaikh, "Madā'ih nathriyya fī hijā' al-malik: al-shu'arā' al-shabāb wa-ma'rakat al-wiṣāya," Aqwās 1 (2001): 6-31; og Khankan, 2009, Chap. 2 "Anthologizers and Other Rewriters: Receiving The Eternal Guests of Fire." 
I5 Anas al-Aili, "Plante" i Ildens evige gæster, 1999, 10.

I6 Alle oversættelser er mine egne, med mindre andet er anført. NK.

I7 F.eks. i vers 2 og 13 uqīm $f \grave{\imath}$ nafsī [jeg bor i mig selv] og i vers 10: atanaffas al-ufuq al-mushmis [jeg indånder den solmættede horisont].

I8 Carol Bardenstein, "Threads of Memory and Discourses of Rootedness: Of Trees, Oranges and the Prickly-Pear Cactus in Israel/Palestine," Edebiyat 8.1 (1998): 1.

I9 Tariq al-Karmi, uddrag fra "Yar'ash al-nawm țāwūsa-hu" [Søvnen ryster sin påfugl], Ildens evige gæster, 1999, 125.

20 Kifah Fanni, uddrag fra "Aḥlām al-nār al-zarqā’’: mu'ālaja rābi'a bi al-azraq dhī al-zill alburtuqālī” [Drømme af blå ild: Fjerde behandling af blå med et strejf af orange] i Mu 'ālajat alfarāgh [Behandlingen af tomhed] (Ramallah: Mațba' Abū Ghūsh, 2004), 90 og 93.

2I Ghassan Kanafani, Rijāl fí al-shams [Mænd i Solen] (Beirut: Dār al-țalī`a, 1963).

22 Walid al-Shaykh, "Haithu lā shajar," Haithu lā shajar [Hvor der ingen træer er] (Ramallah: The House of Poetry, 1999), 81. 